\title{
Prevalence and Associated Risk Factor of COVID-19 and Impacts of Meteorological and Social Variables on Its Propagation in Punjab, Pakistan
}

\author{
Arbab Saddique $^{1} \cdot$ Shahzada Adnan $^{2}$ (1) $\cdot$ Habib Bokhari $^{1} \cdot$ Asima Azam $^{3} \cdot$ Muhammad Suleman Rana $^{4}$. \\ Muhammad Mujeeb Khan ${ }^{5} \cdot$ Muhammad Hanif $^{2} \cdot$ Shawana Sharif ${ }^{6}$
}

Received: 23 December 2020 / Accepted: 10 April 2021 / Published online: 7 July 2021

(c) King Abdulaziz University and Springer Nature Switzerland AG 2021

\begin{abstract}
The current study identifies the spatial distribution of COVID-19 cases and its association with meteorological and social variables in Punjab (densely populated province of Pakistan). To identify the COVID-19 propagation, the weekly growth, recovery, and deaths rate have also been calculated. The geographic information system (GIS) has used to determine COVID19 impacts on gender (male/female), age groups, and causalities over an affected population $\left(\mathrm{km}^{-2}\right)$ for the period of 11 th March to 12th August, 2020 in each district of province. Our results show that 43 peak days (where daily positive cases were above 900) have been observed in Punjab during 27th May to 8th July, 2020. The high population density districts, i.e., Lahore and Islamabad, have been affected (five persons per square kilometers) due to COVID-19, whereas the maximum death tolls ( $>50$ persons per millions) have also been observed in these urban districts. The meteorological variables (temperature, humidity, heat index, and ultraviolet index) show negative significant relationship to basic reproduction number (R0), whereas daily COVID-19 cases are positively correlated to aerosols concentration at $95 \%$ confidence level. The government intervention (stringency index) shows a positive impact to reduce the COVID-19 cases over the province. Keeping in view the COVID-19 behavior and climatology of the region, it has been identified that the COVID-19 cases may likely to increase during the dry period (high concentration of aerosols) i.e., October-December, 2020 and post-spring season (April to June), 2021 in urban areas of Pakistan. This study provides an overview on districts vulnerability that would help the policy makers, health agencies to plan their activities to reduce the COVID-19 impacts.
\end{abstract}

Keywords COVID-19 · GIS · Meteorological variables · Stringency index · Aerosol · Punjab

Shahzada Adnan

shaz.adnan@gmail.com

Arbab Saddique

saddiquearbab@gmail.com

Habib Bokhari

habib@comsats.edu.pk

Asima Azam

asimaazam786@gmail.com

Muhammad Suleman Rana ranavirologist@gmail.com

Muhammad Mujeeb Khan drmujeeb_khan@hotmail.com

Muhammad Hanif hanifwxc@hotmail.com
Shawana Sharif

shawana.sharif@gmail.com

1 COMSATS University Islamabad/Kohsar University, Islamabad/Murree, Pakistan

2 Pakistan Meteorological Department, Sector H-8/2, Islamabad, Pakistan

3 Shaheed Benazir Bhutto Women University, Peshawar, Pakistan

4 National Institute of Health Sciences, Islamabad, Pakistan

5 Holy Family Hospital, Rawalpindi, Pakistan

6 Shaheed Benazir Bhutto Hospital, Rawalpindi Medical University, Rawalpindi, Pakistan 


\section{Introduction}

The outbreak of coronavirus disease (COVID-19) has severely affected many countries of the world. The first case of the virus was observed in early December in Wuhan, China. The World Health Organization (WHO) declared the disease a global pandemic on $11^{\text {th }}$ March, 2020, during which 66 territories outside China were reported 8568 confirmed cases of the virus, with highest numbers observed in Iran and Italy (Hsu et al. 2020). As of 11 th March, 2021, the confirmed cases of COVID-19 around the globe were 118,638,190 including $2,632,074$ deaths. So far, the United States has the highest number of COVID-19 cases with a total of 28,862,124 and 542,191 deaths, while India $(11,285,561)$ and Brazil $(11,205,972)$ have the second and third highest COVID-19 cases, respectively (Worldometer 2020).

The spread of the virus was highest in the neighboring countries of Pakistan, i.e., China in the north and Iran in the west. Initially, the COVID-19 cases were the second highest $(23,042)$ after China till 24th March, 2020 (Tuite et al. 2020; WHO 2020). In Pakistan, foreign transmission (pilgrims and tourists) was the highest (80\%), especially 8000 pilgrims from Iran out of which $60 \%$ were infected with COVID-19 which afterwards reduced to $10 \%$ till 31 st March, 2020 (Badshah et al. 2020). Due to the limited testing facilities, prompt isolation, etc. caused internal transmission, especially in the major cities of Pakistan as the majority of the foreign people returned to their homes (Wilder Smith and Freedman 2020). The first confirmed case of COVID-19 in Pakistan was reported in Karachi (Sindh) and Islamabad on 26th February, 2020 (Noreen et al. 2020a, b). According to the National Institute of Health (NIH), Pakistan's latest COVID-19 update (available on https://covid.gov.pk/stats/pakistan) on 10th March, 2021, the data from all provinces and territories reported a total of 583,916 confirmed cases, 13,013 deaths, 554,255 recovered, 9,246,827 total tests, and 1628 critical cases. Province-wise statistics of Pakistan have shown COVID19 cases of 258,679 in Sindh, 173,395 in Punjab, 72,801 in Khyber Pakhtunkhwa, 44,690 in Islamabad, 19,076 in Balochistan, 10,319 in Azad Jammu Kashmir, and 4956 in Gilgit Baltistan. Among the provinces, the highest number of cases has been reported from Sindh followed by Punjab and Khyber Pakhtunkhwa, Balochistan, and Azad Jammu Kashmir, whereas Gilgit Baltistan was the least affected province (NIH 2021). Currently, Pakistan is the 14th mostaffected country with a fertility rate of 2.23 and a point prevalence of 8.3 , while the peak was observed in the mid of June. Since then, a considerable decline in the number of new cases was noted due to government strategies for effective surveillance and climatic factors (NAPPR 2020).
Punjab is a densely populated province consisting of 36 administrative districts and contributes 52.95\% $(110,012,442)$ of the total population of Pakistan (Census report of Pakistan, 2017). Among 24,104 confirmed cases, 439 deaths with 126 critical cases and 6507 recoveries were reported, whereas the fertility and recovery rate remained $1.8 \%$ and $27 \%$, respectively. The community transmission is reported to be $91 \%$ (Noreen et al. 2020a, b). Punjab's high prevalence and fertility rate can be attributed to a mixture of asymptomatic transmission and its initial untraced spread. The total stands at 2,192 cases with 23 deaths, representing an alarming hike in the number of daily cases since 18 th May, 2020 (100 plus cases daily) with the highest cases (151) reported on 27th May, 2020. According to the census report (2017), the male population contributes almost $50.07-53.09 \%$ of the total population in all the districts of Punjab except Attock, Jhelum, Chakwal, and Khushab, where the female contributes 50.04 to $52.18 \%$ of the total population of these districts.

The world COVID-19 data analysis shows that men have been infected more by COVID-19 as compared to women (Nikpouraghdam et al. 2020). Moreover, a weaker immune system is highly prone to be affected by COVID-19, which makes the older demographic much more susceptible and more likely to be hospitalized due to COVID-19 related complications (CDC 2020). However, several studies from Pakistan depicted that the highest number of individuals which are affected by COVID-19 belong to the 20-29 and 30-39 age groups, while the lowest are in the above 80 (Abid et al. 2020; Noreen et al. 2020a, b; PIDE 2020; Ladiwala et al. 2021 etc.). These data seem paradoxical given that the elderly are more susceptible to the virus owing to a weakened immune system and poor health (Clark et al. 2020), but this disparity can be explained by looking closely at Pakistan's demographic and social structure. According to the United Nation's data, only 4\% of Pakistan's population is above 65 , while the average age is 22.5 . This is in stark contrast to the highly affected countries such as Italy, where 23\% of the population is above 65 and the average age is 47 . Italy has the second highest oldest population in the world after Japan (OECD, 2021). Initially, the slow response, testing capacity, family culture, and old age population are the main reasons for high mortality rate in Italy and other European countries. An elderly and unhealthy individual is likely to suffer more fatally from the viral infection due to their weak immune system (CDCP 2020).

Numerous studies (Chan et al. 2011; Paz and Semenza 2016; Lee and Chowell 2017; Morin et al. 2018; Keilman 2019 , etc.) have identified that the weather plays significant role to lessen the spread of infectious disease like influenza, pneumonia, and flue, etc. during winter and dengue fever, chicken pox, and typhoid in summer season. Theses all diseases are highly associated with the diurnal temperature 
range. Recently, many researchers around the world conducted studies and identified the meteorological parameters (temperature, humidity) impact on COVID-19 spread (Qi et al. 2020; Livadiotis 2020; Shi et al. 2020; Iqbal et al. 2020). Similarly, Bashir et al. 2020 identified that the temperature and air quality suppress COVID-19 significantly. The UV light helps to minimize the spread of microbial disease and remain effective for viral disease like flu and influenza (Welch et al. 2018; Budowsky et al.1981; McDevitt et al. 2012; Ko et al.2000). A significant nonlinear association has been observed among daily COVID-19 cases, meteorological variables, and air quality index on different lag days over Dhaka (Islam et al. 2021). Similarly, the dust particles inhaled by humans can damage the respiratory system and immunity causing high vulnerability to COVID-19 infection (Chen et al. 2021).

Geographic information system (GIS) is very helpful in mapping of spatial monitoring, disease spread, disease cases, risk assessment etc. (Mollalo et al. 2018). GIS algorithms facilitate early detection and outbreak of disease over a spatial area (Meng, 2017). In early times, the health agencies were highly dependent on old traditional methods to control and monitor the infectious disease, which take long time to detect and identify the spread of disease. Many researchers have used GIS to identify the spatiotemporal disease mapping, risk assessment and surveillance, etc. (Franch-Pardo et al. 2020; Sarwar et al. 2020; Sugg et al., 2021 etc.). In this study, GIS helped to analyze the COVID-19 cases in genders, age groups as well as infected patients over a population density $(\mathrm{km} 2)$ and mortality in each of the districts. The current study identifies the propagation, growth, recovery, and death rate of COVID-19 cases in the Punjab province. The study determines impacts of COVID-19 on gender, age group, and fatality over positive patient density $\left(\mathrm{km}^{-2}\right)$ in each district of Punjab. Moreover, the meteorological and social variables are used to identify their impacts on COVID-19 propagation over the Punjab province. The relationship and impact of these variables on COVID-19 may help the scientific community, epidemiologist, policy makers, and health agencies to understand the behavior, response, transmission, spread, as well as propagation. The aptitude of detection of disease pattern in different districts of Punjab would help in the efficiently planning strategies for disease control and prevention as well as provide information for further epidemiological studies to analyze disease transmission.

\subsection{Data and Methodology}

The daily data of COVID-19 (tests, patients) for each district of Punjab have been collected from the National Institute of Health (NIH), Ministry of Health, Pakistan for the period of $11^{\text {th }}$ March to $12^{\text {th }}$ August, 2020. In addition, the daily observational data of temperature $\left({ }^{\circ} \mathrm{C}\right)$ and relative humidity (\%) are obtained from Pakistan Meteorological Department (PMD). We calculated heat index (HI) which is the combination of temperature and relative humidity over the province as determined by Steadman, 1979. Moreover, the daily ultraviolet Index (UVI) and Aerosols optical Depth (AOD) data, with a spatial resolution of $1^{\circ} \times 1^{\circ}$, have obtained from the Ozone Monitoring Instrument (OMI), onboard NASA's Aura spacecraft (Torres 2006), and available at the following web-link: https://giovanni.gsfc.nasa.gov/giovanni/. Some researchers have used MODIS satellite AOD data for sand and dust storm monitoring and try to develop its relationship to various meteorological parameters over Saudi Arabia (Butt et al. 2017; Butt and Mashat 2018; Labban and Butt 2021).

To identify the COVID-19 affected patients over gender and various age groups, we first converted the affected population of male and female over per million populations, i.e., the number of affected male/female over the total number of male/female then multiplied by 106 to convert into million. Similarly, the number of deaths per million as well as affected population density has also been calculated. Second, we classified the population into four age groups, i.e., teenage (0-19), young (20-40), aged (41-60), and senior citizen $(>60)$, and then calculated the percentage of affected patient for each group in entire districts of Punjab. GIS has been used to display the data over each of the districts.

The data of the stringency index (SI) are acquired from https://ourworldindata.org/grapher/covid-stringency-index. This index is created by the University of Oxford which determines the effectiveness of lockdown, and it ranges from 0 to 100. According to Hale et al. 2020, SI is based on various indicators like schools closure, workplace closures, cancel public events, restrictions on gatherings, close public transport, public information campaigns, stay at home, restrictions on internal movement, international travel controls, testing policy, contract tracing, face coverings and vaccination policy, etc. The higher values of SI indicate a high level of stringency over the region. The both indices, i.e., HI and UVI, are used to identify the impacts and their association with basic reproduction number (R0), whereas stringency index and aerosols concentration are correlated with daily positive COVID-19 cases over Punjab province. The geographical location and elevation of Punjab districts are shown in Fig. 1.

The positivity, growth, recovery, and mortality rate have been calculated. Positivity rate $\left(\mathrm{P}_{\mathrm{r}}\right)$ is the ratio between total positive patients $\left(\mathrm{P}_{\mathrm{pt}}\right)$ over the number of tests $\left(\mathrm{T}_{\mathrm{t}}\right)$ (Eq. 1):

Positivityrate $=\frac{P_{p t}}{T_{t}}$ 


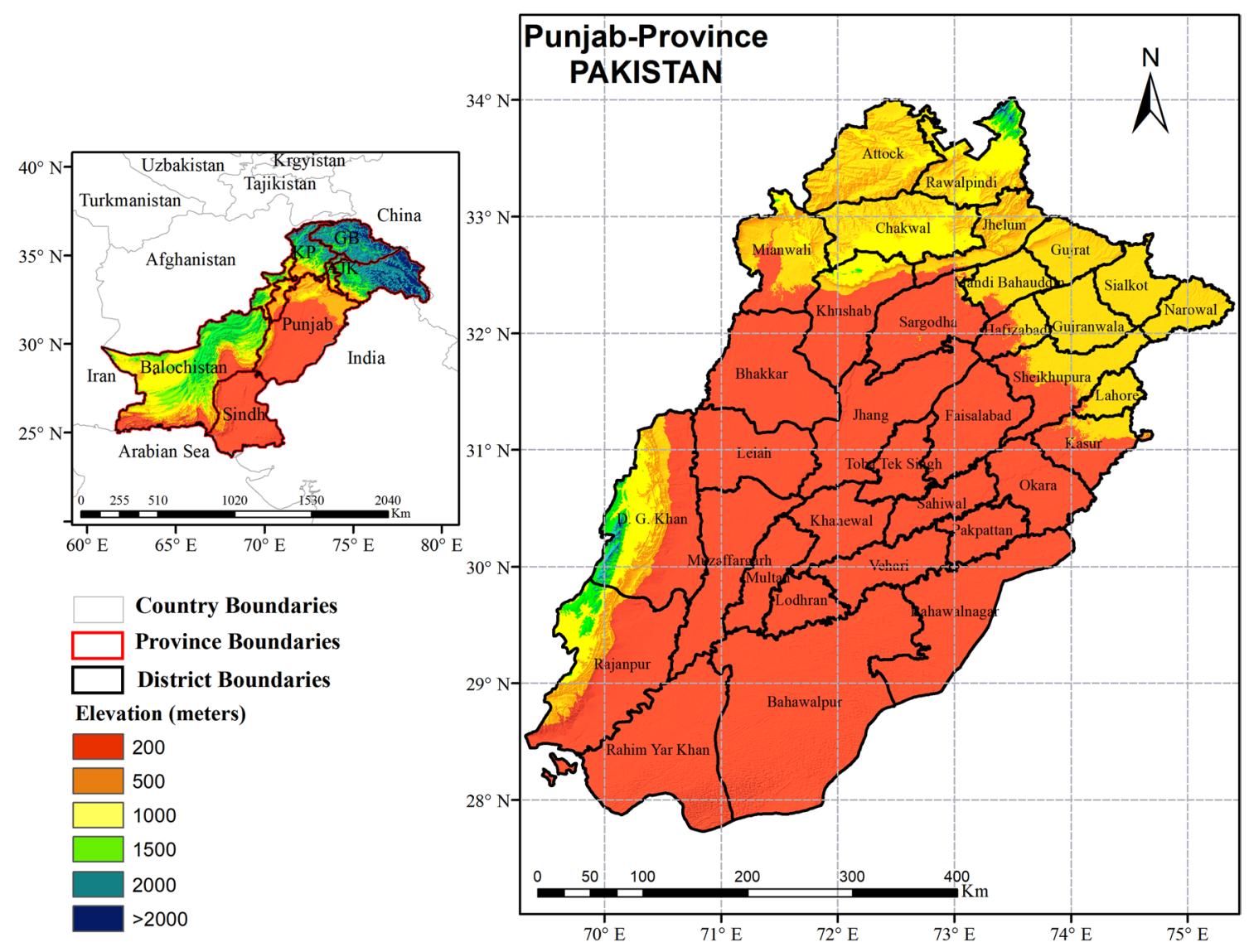

Fig. 1 Geographical location along with elevation of districts of Punjab

The growth rate $\left(\mathrm{G}_{\mathrm{r}}\right)$ is the ratio between numbers of new cases 1 day $\left(\Delta N_{d}\right)$ to the new cases the previous day $\left(\Delta N_{d-1}\right)$ or it is defined as the ratio between two successive changes (Ridenhour et al. 2018) (Eq. 2):

Growthrate $=\frac{\Delta N_{d}}{\Delta N_{d-1}}$.

Recovery rate $\left(\mathrm{R}_{\mathrm{r}}\right)$ is the ratio between numbers of recovered patient $\left(R_{p t}\right)$ to the total positive patients $\left(\mathrm{P}_{\mathrm{pt}}\right)$ (Eq. 3):

Recoveryrate $=\frac{R_{p t}}{P_{p t}}$

Mortality rate $\left(\mathrm{M}_{\mathrm{r}}\right)$ is the ratio between numbers of deaths $\left(D_{t}\right)$ to the total positive patients $\left(\mathrm{P}_{\mathrm{pt}}\right)$ (Eq. 4):

Mortalityrate $=\frac{D_{p}}{P_{p t}}$.

Basic reproductive number $\left(\mathrm{R}_{0}\right)$ is not a biological constant for a pathogen; however, it determines the expected number of cases directly generated by one case in a population where all individuals are susceptible to infection.
$\mathrm{R}_{0}$ is the ratio between the fractions of individual susceptible per day $(\beta)$ to the fraction of recoveries $(\gamma)$ defined by Diekmann et al. 1990 (Eq. 5):

$R_{0}=\frac{\beta}{\gamma}$.

The value of $R_{0}>1$ represents the spread of epidemic, whereas the $\mathrm{R}_{0}<1$ shows the reduction in the spread of disease.

The correlation was calculated using Pearson methods, whereas $t$ test has been used to determine the significance at 95\% confidence level.

\section{Results and Discussion}

To determine the variation in COVID-19, the daily and weekly analysis was conducted over the Punjab province. The first COVID-19 case was reported on $15^{\text {th }}$ March 2020 in Punjab, while the tests started 4 days earlier (11th March, 2020). Initially, most of the cases were foreign transmission. The daily tests were below 3000 up to 30th April, 2020. 
The government provided free testing facility by setting up a dedicated COVID-19 cell in the hospital. Furthermore, the track and test approach was also used to identify the COVID-19 patients. Meanwhile, the daily number of new cases started to increase due to local transmission and the government increased the daily tests facilities in the province after April. The highest tests $(11,739)$ were conducted on 17th June, whereas the highest positive patients $(2,705)$ in day were reported on 12th June 2020 (Fig. 2a). Overall, about 785,764 COVID-19 tests were conducted and 94,865 patients reported positive, 86,389 recovered, and 2179 died during 11th March to 12th August, 2020 in the province. Forty-three peak days were experienced during 27th May to 8th July, 2020 over the whole province where the daily positive cases were above 900 (Fig. 2).

The total recovered patients from COVID-19 were 86,389 up to 12th August, 2020, due to which the number of active cases reduced to 8476 . The maximum patient recovered during $27^{\text {th }}$ June to $13^{\text {th }}$ July, 2020, whereas the highest patient recovered in a day were 12,802 on 24th July, 2020 (Fig. 2b). The total deaths were 2133 during the whole data period. The daily death peak period was observed from 27 th May to 8th July, 2020, with the highest deaths (86) in a day on 24th June 2020 (Fig. 2c).

The weekly positivity, growth, recovery, and mortality rate of COVID-19 have been calculated for the Punjab province since 11th March, 2020 (Fig. 3). The positivity rate $\left(\mathrm{P}_{\mathrm{r}}\right)$ defines as the ratio between patients to test, whereas the growth rate $\left(G_{\mathrm{r}}\right)$ is the difference between two successive changes of COVID-19 cases. The peak time period of Pr remained between 10 and $18^{\text {th }}$ weeks (13th May and 14th July), whereas it was the highest (24.6) in 13th week (3-9th June), as shown in Fig. 3a. Similarly, $G_{r}$ was the highest (10.38) on the 2nd week (18-24th March) and it consistently dropped. Later on, $\mathrm{G}_{\mathrm{r}}$ was below one after the 14th week (17th June, 2020) except the 17 th

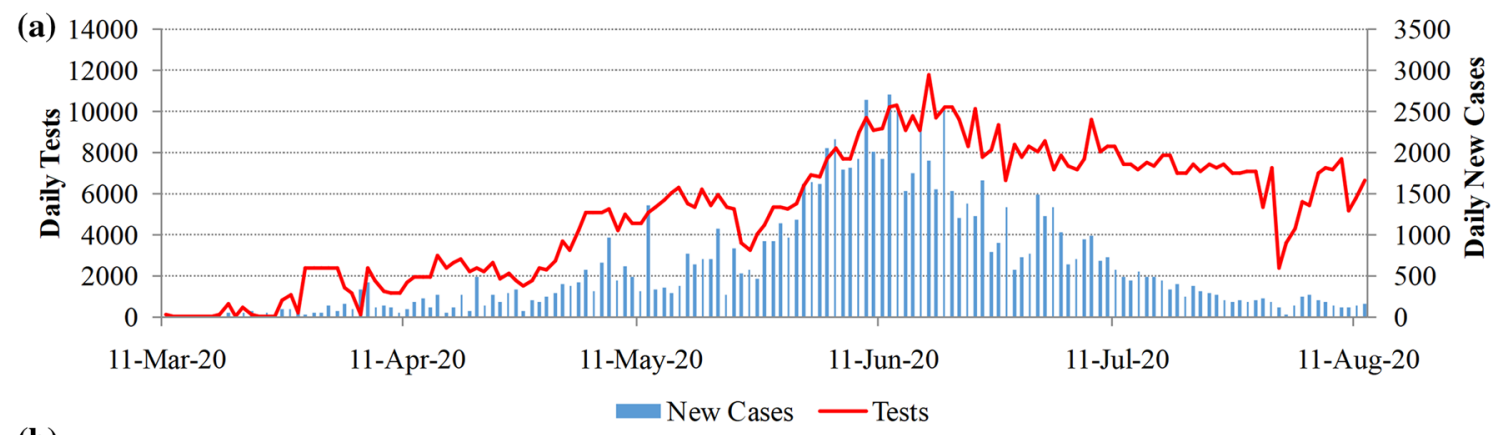

(b)

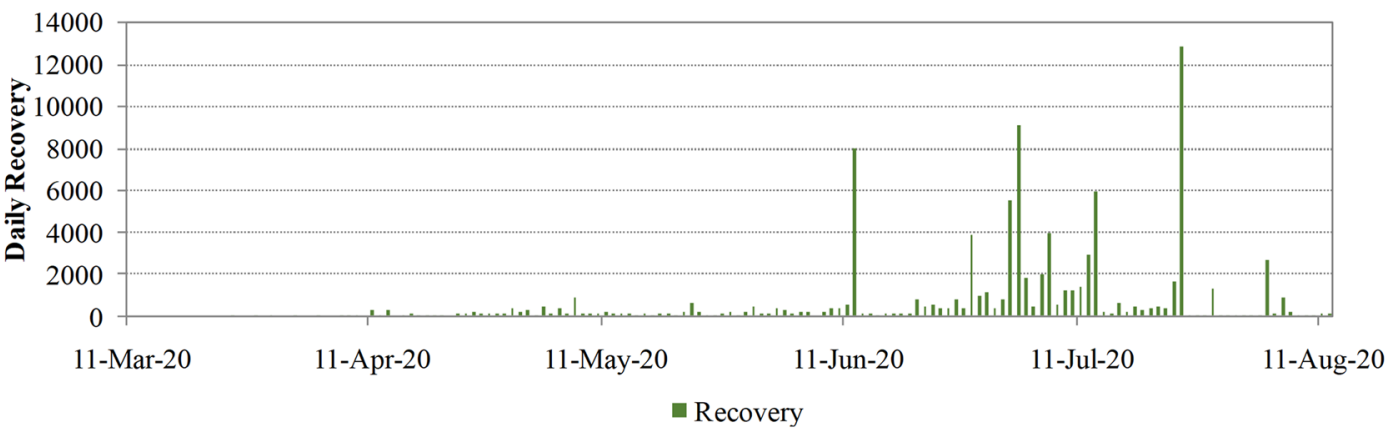

(c)

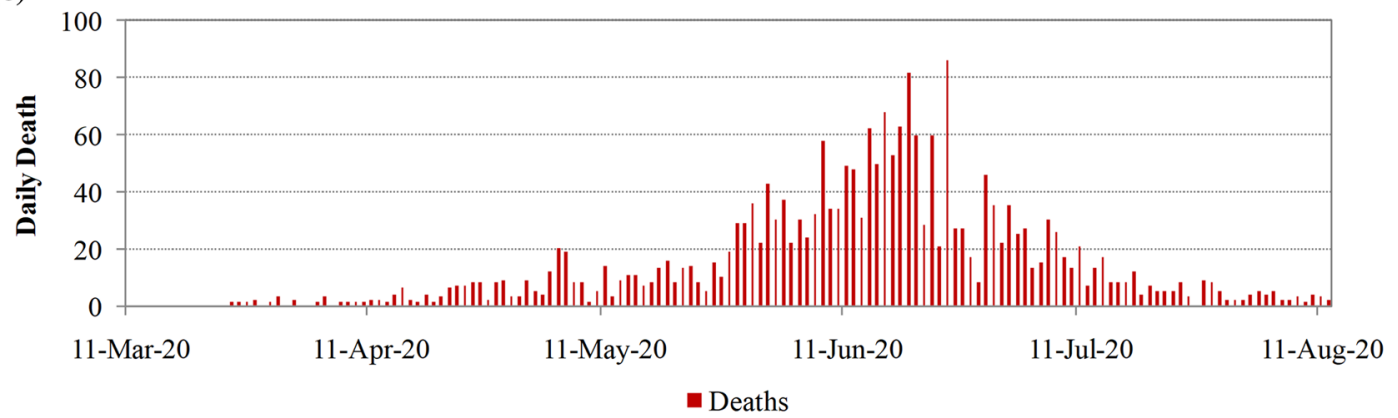

Fig. 2 The details of a daily tests, new cases, $\mathbf{b}$ recovery, and $\mathbf{c}$ death data of COVID-19 in Punjab province 


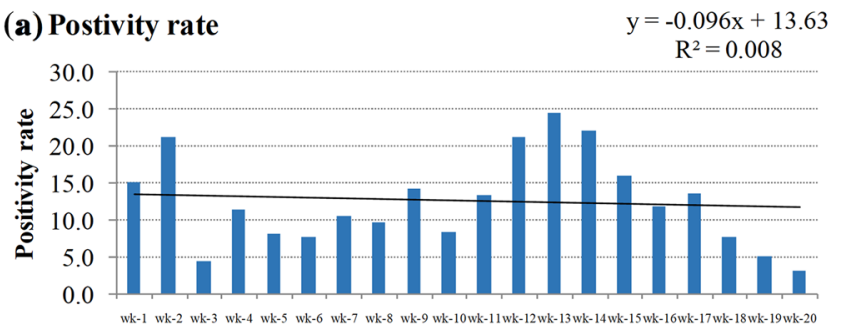

(c) Recovery rate

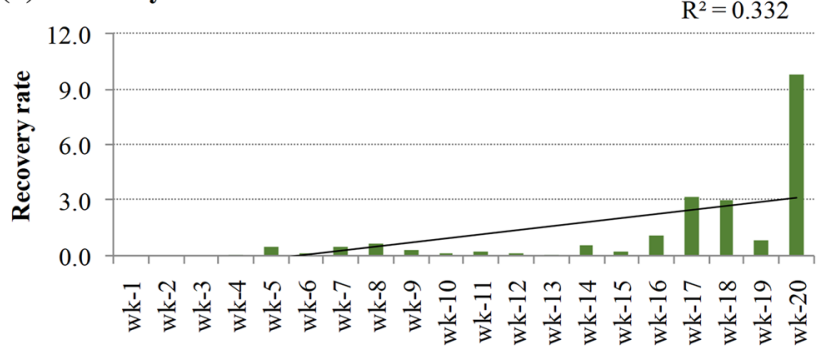

(b) Growth rate

$y=-0.153 x+3.251$ $\mathrm{R}^{2}=0.173$

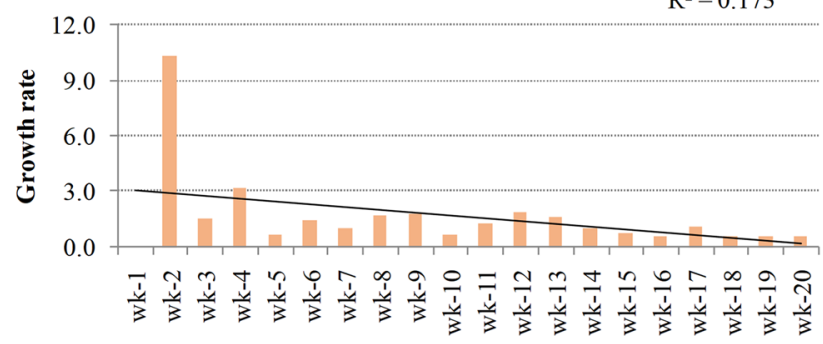

(d) Mortality rate

$\mathrm{y}=0.102 \mathrm{x}+0.860$

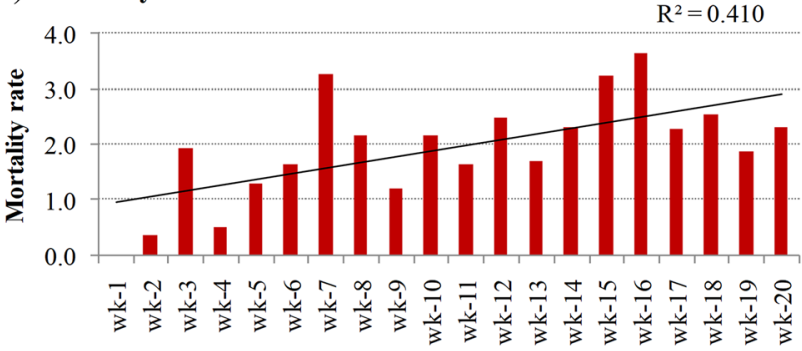

Fig. 3 Weekly positivity rate, growth rate, recovery rate, and mortality rate of COVID-19 in Punjab province

week, where it remained 1.07 (Fig. 3b). The recovery rate $\left(\mathrm{R}_{\mathrm{r}}\right)$ was initially low (below 1) but increased after the 15th week on 17th June. The peak period of $R_{r}$ was between 16 and 20th week, while it was the highest (9.83) in the 20th week (22-28th July), as shown in Fig. 3c. The weekly mortality rate $\left(\mathrm{M}_{\mathrm{r}}\right)$ remained $0.37-3.66$ in the province. Figure $3 \mathrm{~d}$ shows that the peak period remained between the $13^{\text {th }}$ and $20^{\text {th }}$ weeks with the highest $\mathrm{Mr}$ (3.66) in the $16^{\text {th }}$ week ( $24^{\text {th }}$ June).

The weekly positivity, growth, recovery, and mortality rate of COVID-19 have been calculated for the Punjab province since $11^{\text {th }}$ March, 2020 (Fig. 3). The positivity rate $\left(\mathrm{P}_{\mathrm{r}}\right)$ defines as the ratio between patients to test, whereas the growth rate $\left(G_{r}\right)$ is the difference between two successive changes of COVID-19 cases. The peak time period of $\mathrm{P}_{\mathrm{r}}$ remained between 10 and $18^{\text {th }}$ weeks (13th May and 14th July) whereas, it was the highest (24.6) in 13th week (3-9 $9^{\text {th }}$ June), as shown in Fig. 3a. Similarly, $G_{r}$ was the highest (10.38) on the $2^{\text {nd }}$ week (18-24th March) and it consistently dropped. Later on, $\mathrm{G}_{\mathrm{r}}$ was below one after the 14th week (17th June, 2020) except 17th week, where it remained 1.07 (Fig. 3b). The recovery rate $\left(\mathrm{R}_{\mathrm{r}}\right)$ was initially low (below 1), but increased after the 15 th week on 17 th June. The peak period of $\mathrm{R}_{\mathrm{r}}$ was between 16 and 20th week, while it was the highest (9.83) in the 20th week (22-28th July), as shown in Fig. 3c. The weekly mortality rate $\left(\mathrm{M}_{\mathrm{r}}\right)$ remained $0.37-3.66$ in the province. Figure $3 \mathrm{~d}$ shows that the peak period remained between 13 and 20th weeks with the highest $M_{r}(3.66)$ in the 16th week (24th June).

\section{Geo-spatial Analysis}

Pakistan is experiencing a high number of COVID-19 cases, with the maximum share from Punjab, Pakistan (Saeed et al. 2021). The numbers of affected population (male and female) per million due to the COVID-19 have been determined in 36 districts of the province including Islamabad (Fig. 4). The results show that the highest male population ( $>500$ ) per million was affected in Lahore, Rawalpindi, and Multan due to COVID-19, whereas it was between 300 and 500 per million in Sialkot, Gujranwala, Hafizabad, Faisalabad, and DG Khan region. Similarly, the highest female affected population $(>500)$ per million was observed in Lahore, whereas it was between 300 and 500 per million in Rawalpindi and 200 and 300 in Multan and Faisalabad region.

It has been observed that the majority of the male population was affected due to COVID-19 in the province as the male family members have to go outside for work and their interaction with the community is more than female. However, more females were affected due to COVID-19 than males in Attock and Bakkar districts. The majority of the population is female in Attock, whereas most of the females work in agriculture fields and associated with agriculture activity in Bhakkar and have become more exposed to COVID-19. The districts of Lahore, Multan, and Rawalpindi are the business hub and the majority of the males traveled to these cities for the work. More 
Fig. 4 Number of male and female affected per million due to COVID-19 in various districts of Punjab province
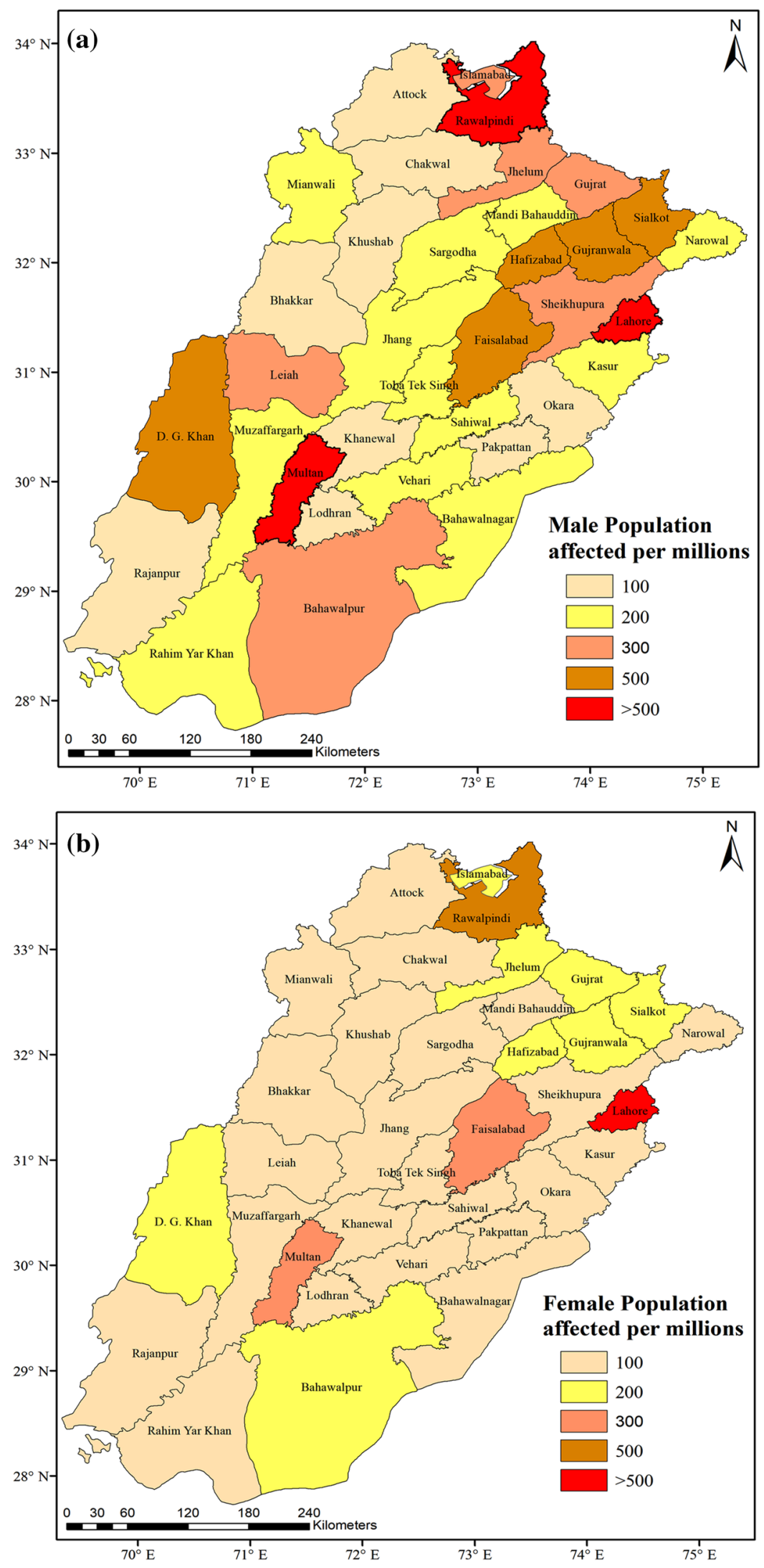
importantly, these districts have high population density and the medical and hospital facilities are much better.

The percentage of COVID-19-affected patients over various age groups (teenage, young, aged, and senior citizen) has been calculated in the entire districts of Punjab (Fig. 5). It has observed that $10-25 \%$ of teenagers were affected in the majority districts of Punjab. The highest ( $>90 \%)$ of affected patients in the teenage group were observed in Bhakkar districts followed by Jhang and Khushab, where it was $50 \%$. Similarly, almost $50 \%$ of the young people were affected in 22 districts and $75 \%$ in 14 districts, whereas no young age group patient was reported in Bhakkar district. The results
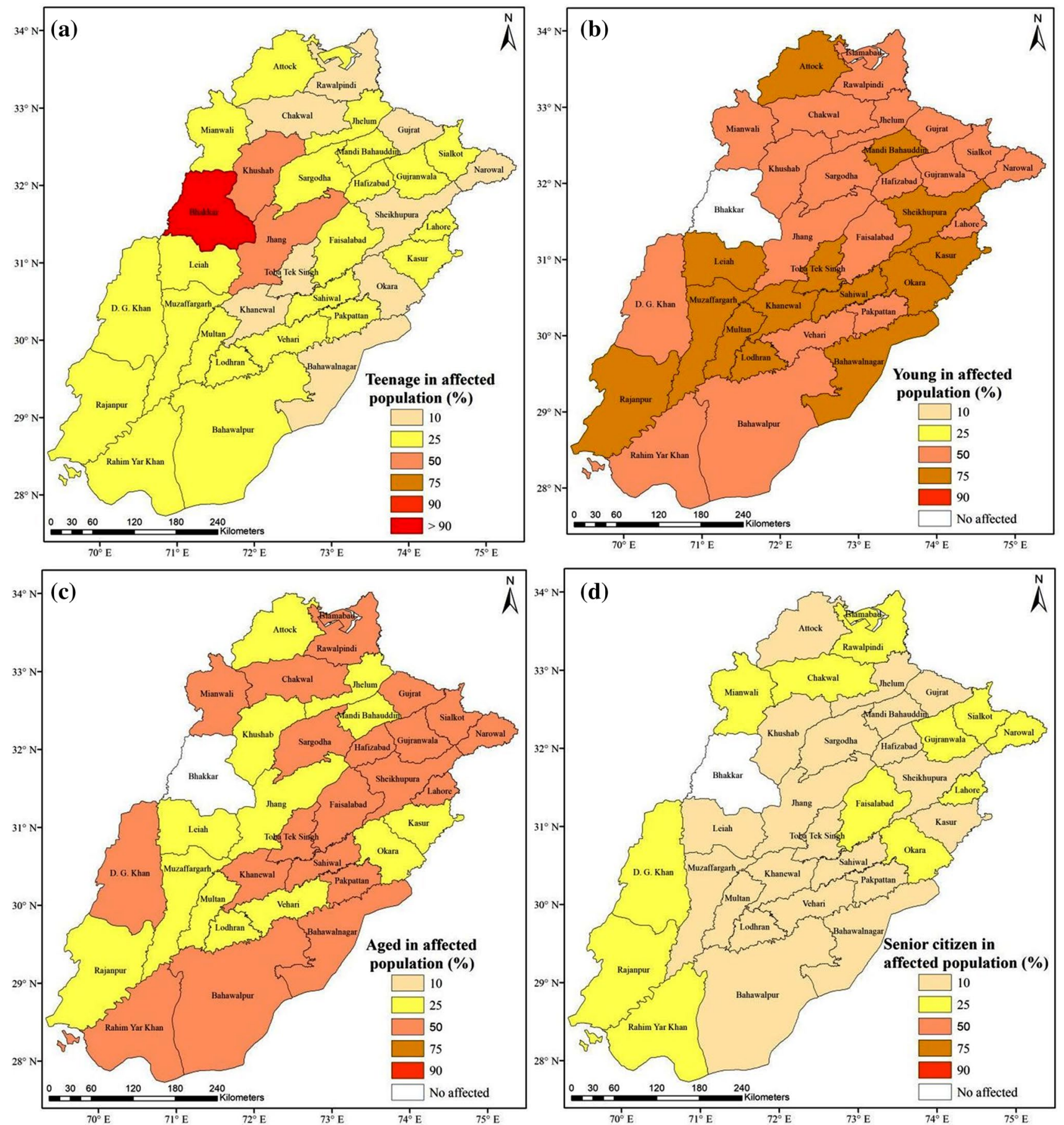

Fig. 5 Percentage of affected population: a Teenage, b Young, $\mathbf{c}$ Aged, and $\mathbf{d}$ Senior Citizen due to COVID-19 in various districts of Punjab province 
also show that $25 \%$ of the aged group has been affected in 13 districts and $50 \%$ in 23 districts including Islamabad. Moreover, $10 \%$ of senior citizens were affected in 23 and $25 \%$ in 13 districts of Punjab. The results also show that $25 \%$ of the aged group has been affected in 13 districts and $50 \%$ in 23 districts including Islamabad. Moreover, $10 \%$ of senior citizens were affected in 23 and $25 \%$ in 13 districts of Punjab. The COVID-19 has affected most of the females than males in Bhakkar (Fig-4). Normally, the female took their children (teenagers) along with them in the fields, so that they can look after them easily and their children may help them in daily routine activity carried out in the agriculture field.

May and June are the harvesting and sowing season of Rabi (Wheat) and Kharif (Cotton, rice and Maize) crops, respectively. Most of the people living in rural districts work in fields and ignored the standard operating procedure like using of masks and social distancing etc. due to unawareness and non-seriousness of the problem. In order to overcome this problem, the government should start awareness programs and strict compliance with its order should be implemented through local administration. The results showed that COVID-19-positive cases were higher during the months of May and June. More importantly, the provincial administration eased the lock down in the province and people living in and around the urban cities started to work in the city. Most of the people moved towards the major cities in the province to earn their livelihood. Due to which, the COVID-19 spike was experienced in these districts.

The maximum number of deaths per million has occurred in the districts of Lahore, Rawalpindi, and Islamabad where it was greater than 50 persons per million, whereas 50 persons per million died in the districts of Sialkot, Gujranwala, Sheikhupura, and Multan (Fig. 6). The death tolls are high in the urban districts with high population density. According to the world air quality index (2021), the air quality of major cities of Punjab, i.e., Lahore, Gujranwala, Faisalabad, Multan, Rawalpindi, and Sialkot, are very poor. However, Lahore ranks at the top among the rest of the cities where the air quality index remains worst throughout the year, whereas the pollen allergy is common during the spring season in twin cities, i.e., Rawalpindi and Islamabad. The respiratory disease is more common in the inhabitants of these areas, and they have become highly susceptible to COVID-19 impact which directly affects the lungs creating suffocation and causing death. The recent study shows that death rate
Fig. 6 Number of deaths per million and populations affected $\left(\mathrm{km}^{-2}\right)$ due to COVID-19 in districts of Punjab

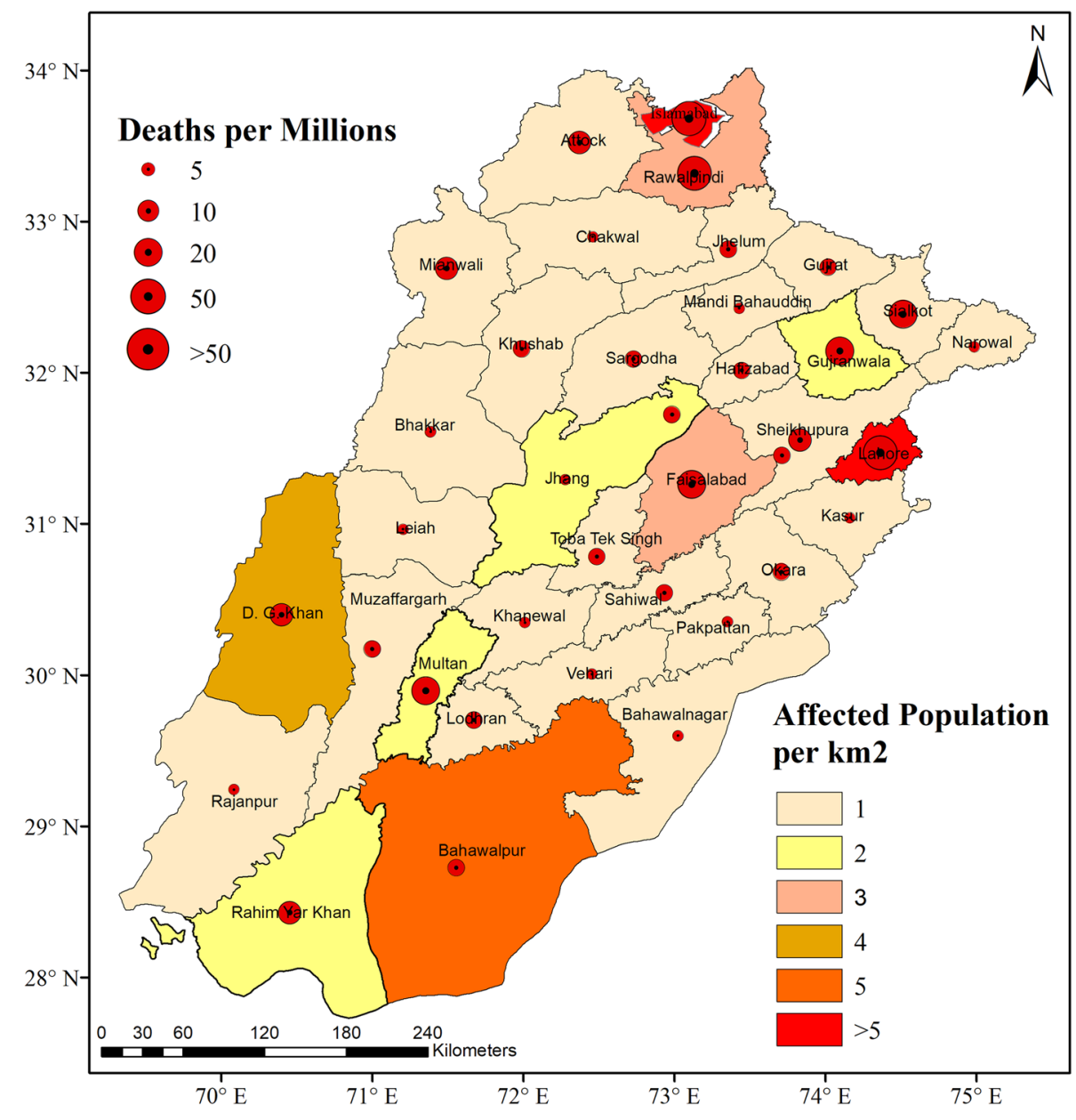


remains high in poor air quality region as people in that region are highly exposed to bad environment and become victims of chronic diseases (Wu et al. 2020).

Population affected per square kilometers (ratio between positive patients to the population density) of each district was calculated which showed COVID-19 transmission rate was high in densely populated regions (Fig. 6). However, the majority of the foreign transmissions are observed in DG Khan and Bahawalpur districts, where lots of pilgrims from the neighboring countries, especially Iran, are quarantined in quarantine centers. The highest affected population per square kilometers was observed in Lahore and Islamabad where it was greater than 5 persons per $\mathrm{km}^{2}$.

\subsection{Impact of Weather and Government Intervention on COVID-19}

The monthly climatology of various meteorological variables over Punjab province is shown in Table 1. The results show that mean monthly air temperature remains the lowest $\left(11.1^{\circ} \mathrm{C}\right)$ in January and the highest in June $\left(32.2^{\circ} \mathrm{C}\right)$, whereas the relative humidity remains the highest (69.9) in December. However, the heat index is only observed during May-September, where the highest value is observed in July $\left(36.1{ }^{\circ} \mathrm{C}\right)$. The UV index remains high during May-August, whereas the highest aerosols concentration (0.61) is observed during May, which is the direst (lowest humidity) month of the year.

Based on the daily COVID-19 cases, the basic reproductive number was calculated for the Punjab province. It has found that basic reproduction number $\left(\mathrm{R}_{0}\right)$ ranged for 1.01-3.8 in the province with maximum at Lahore (1.01-4.2) as well as in Islamabad (1.01-4.1). The temperature has the highest range $\left(38.4\right.$ to $\left.40.9^{\circ} \mathrm{C}\right)$ during 21 st to 27th May and 14th to 20th June, 2020, whereas the relative humidity (RH) consistently increased ( $>55 \%)$ after $1^{\text {st }}$ July, 2020 and it was the lowest $(<25 \%)$ between 17 and 28th May, 2020. Moreover, HI and UVI are found to be rapidly increased after 20th May, 2020 with a maximum $52.4{ }^{\circ} \mathrm{C}$ and 11.53 at Lahore respectively. The stringency index was the highest (96.3) during 26th March-14th April, 2020. The aerosol concentration was highest during 20th April-20th June, 2020 due to dry weather conditions and low humidity, which is the climate of the region. Most importantly, wheat harvesting remains at its peak which enhances the aerosols concentrations during this period. The low humidity increases the aerosols suspension in the atmosphere as compared to high humidity, where these aerosols are deposited rapidly in the ground.

Pearson correlation analysis has been done for temperature, RH, HI, and UVI with respect to R0, whereas aerosol concentration and stringency index with respect to daily positive COVID-19 cases over Punjab province (Fig. 7). The results show that temperature, $\mathrm{RH}, \mathrm{HI}$, and UVI is negatively correlated to R0. Moreover, the aerosols and stringency index were positively and negatively correlated to daily positive cases, respectively. The correlation is statistically significant at the $95 \%$ confidence level (Table 2).

The high temperature is observed during May and June, which is known as the hottest months in Punjab, whereas the humidity remained lower than the rest of the months. The HI starts to develop from the mid of June till 20th August due to the increase in humidity. Moreover, the UV index is also observed high during summer (May-September), because the sun is high in the sky, and its rays arrive more directly and travel through much less zone than in winter where the sun is lower in the sky. These all meteorological parameters significantly impacted to lessen the COVID-19
Table 1 Monthly climate of various meteorological variables over Punjab Province

\begin{tabular}{llllll}
\hline Months & $\begin{array}{l}\text { Mean tempera- } \\
\text { ture }\left({ }^{\circ} \mathrm{C}\right)\end{array}$ & $\begin{array}{l}\text { Relative humid- } \\
\text { ity }(\%)\end{array}$ & Heat index $\left({ }^{\circ} \mathrm{C}\right)$ & UV index & $\begin{array}{l}\text { Aerosol } \\
\text { concentra- } \\
\text { tion }\end{array}$ \\
\hline Jan & 11.1 & 69.3 & $*$ & 3 & 0.31 \\
Feb & 13.8 & 62.1 & $*$ & 5 & 0.27 \\
Mar & 18.8 & 55.1 & $*$ & 7 & 0.29 \\
Apr & 24.8 & 40.1 & $*$ & 9 & 0.36 \\
May & 29.9 & 34.6 & 29.1 & 11 & 0.61 \\
Jun & 32.2 & 42.9 & 33.1 & 12 & 0.45 \\
Jul & 30.9 & 65.7 & 36.1 & 12 & 0.54 \\
Aug & 30.0 & 71.4 & 35.3 & 11 & 0.49 \\
Sep & 28.3 & 65.0 & 30.6 & 9 & 0.43 \\
Oct & 23.8 & 57.8 & $*$ & 6 & 0.44 \\
Nov & 18.2 & 63.6 & $*$ & 4 & 0.37 \\
Dec & 13.0 & 69.6 & $*$ & 3 & 0.35 \\
\hline
\end{tabular}

*No heat index $\left({ }^{\circ}\right)$ is observed during these months 

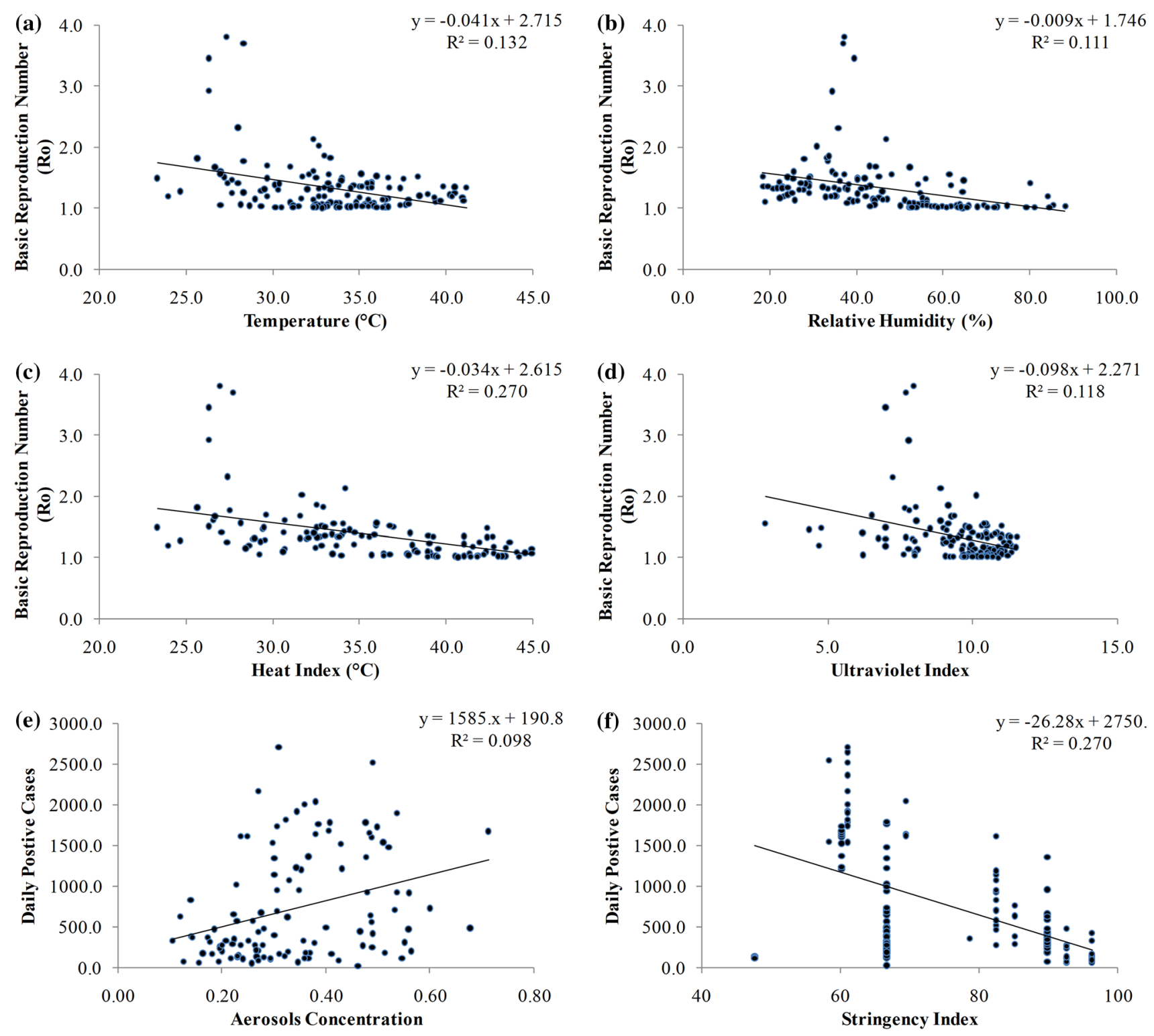

Fig. 7 Scatter plot of impact of weather and government intervention with respect to COVID-19 for Punjab province. a Temperature $\left({ }^{\circ} \mathrm{C}\right)$. $\mathbf{b}$ Relative humidity (\%). c Heat index. d Ultraviolet index. e Aerosol concentration. f Stringency index

Table 2 Correlation analysis of meteorological parameters and stringency index with respect to basic reproduction

\begin{tabular}{lll}
\hline Parameters & Ro & $\begin{array}{l}\text { Daily } \\
\text { positive } \\
\text { cases }\end{array}$ \\
\hline Temperature $\left({ }^{\circ} \mathrm{C}\right)$ & $-0.36^{*}$ & \\
Relative humidity $(\%)$ & $-0.33^{*}$ & \\
Heat index $\left({ }^{\circ} \mathrm{C}\right)$ & $-0.52^{*}$ & \\
Ultraviolet index & $-0.34^{*}$ & $0.30^{*}$ \\
Aerosols concentration & & $-0.48^{*}$ \\
Stringency index & & \\
\hline
\end{tabular}

${ }^{*}$ The values are statistically significance at $95 \%$ level projection over the Punjab province. The same results have been obtained by Adnan et al. 2020 over the major cities of Pakistan. Moreover, the aerosol concentration was high during May and June due to which the COVID-19 cases increased rapidly during these two months. However, the COVID-19 cases declined due to the arrival of the monsoon system (July to September), which normally enhances the humidity and reduces the aerosols concentration in the atmosphere. The government timely and precisely intervention also favored the rising trend of COVID-19 over the Punjab province.

The results clearly show that COVID-19 daily positive cases and its basic reproduction number (R0) decreased 
significantly on the following threshold, i.e., for temperature $\left(\geq 30{ }^{\circ} \mathrm{C}\right)$, Humidity $(\geq 55 \%)$, HI $\left(\geq 33^{\circ} \mathrm{C}\right)$, UVI ( $\geq 9.5$ ), aerosol concentration ( $\geq 0.30$ ), and stringency index $(\geq 65)$ in Punjab province. The respiratory disease spread rapidly during cold and dry conditions (Davis et al. 2016a, b). Similarly, the COVID-19 transmission significantly decreases due to increase in temperature and humidity as identified by many researchers (Abduljali and Abduljali, 2020; MA et al. 2020; Loeffelholz and Tang, 2020 etc.). Altamini and Ahmed (2019) identified that the MERS-CoV broke out in Riyadh, Saudi Arabia during summer due to low humidity. It has already been determined that higher humidity reduces the transmission and spread of respiratory droplets like influenza and settles them rapidly to the ground (Lowen et al. 2007).

The government made three interventions in terms of lockdown (partial, complete, and smart) during the COVID-19 onset to decline period. The COVID-19 cases were small in number during 16th to 22nd March, 2020 in which partial lockdown was implemented in which public/private schools, offices, parks, and shops were closed. The country was under a complete lockdown during 23rd March-14th April, 2020 in which free movement of the public was restricted and all the public/private schools, offices, parks, shops, airports, and public inter/outer city transport remained closed, while the groceries' stores and some government important offices with less staff were opened. Most importantly, the business hours duration was reduced from $8 \mathrm{~h}$ ( $9 \mathrm{am}$ to $5 \mathrm{pm}$ ) to $6 \mathrm{~h}$ (10am to $4 \mathrm{pm})$. Moreover, the track and trace program to identify the COVID-19 cases was launched. The smart lock was implemented after 15th April, 2020, and those areas were sealed where high positive COVID-19 was observed. The business centers, offices, markets, parks, schools, public transports, and shops were opened gradually. The daily business hours increased up to 9 am to $10 \mathrm{pm}$. The smart lockdown along with standard operating procedure (social distancing, use of mask, etc.) helped a lot to reduce the COVID-19 wave in the country as well as in Punjab.

The massive media campaign and awareness programs were also launched to bring comprehension to the general public. The mobile companies aired the messages (text and audio) regarding COVID-19 precautionary measures. More importantly, weather also played a significant role to subside the COVID-19 cases after the mid-June, 2020. Recent study shows heat index (temperature, humidity) and ultraviolet index played significant role to subside COVID-19 over major cities of Pakistan including Lahore (Adnan et al. 2020). The cities of Lahore and Islamabad are the hub of business, financial and government functionaries, and the majority of the population traveled there each day from the neighboring regions. Most importantly, the population density of these two districts is very high as compared to the rest of the districts, and these remained more vulnerable to COVID-19.

\section{Conclusion}

Punjab is the largest and densely populated province of Pakistan. Based on the above results, it is concluded that total 785,764 COVID-19 tests were conducted out of which 94,865 patients reported positive, 86,389 recovered, and 2179 died during 11th March-12th August, 2020 in the province. The COVID-19 peak period (daily positive cases $>900$ ) remained during 27th May-8th July, 2020 over which 43 peak days were observed in the province. The weekly analysis show peak duration for the positivity rate was 10th to 19th week (13th to 14th July), whereas it was highest in 13th week (3-9th June). Growth rate was higher in the 2nd week (18-24th March), while maximum recovery rate was observed during the 16th to 20th week. Moreover, the mortality rate remained $0.37-3.66$ with a peak in the 16 th week $\left(24^{\text {th }}-30\right.$ th June). The districts of Lahore, Islamabad, Rawalpindi, and Multan were the highly vulnerable districts regarding COVID-19. Significant negative correlation (at 95\% level) has observed for temperature $(-0.36)$, RH ( -0.33$)$, HI (-0.52), and UVI ( -0.34$)$ to R0, whereas daily COVID-19 cases were positively correlated to aerosols $(0.30)$ and negative to stringency index $(-0.48)$ over Punjab province. The highest increase in the daily positive cases was observed during May-June, 2020 when RH was the lowest and aerosol concentration was highest due to dry conditions. This study identified that the COVID-19 affected the urban areas more than rural areas, especially those where the population was congested and there was a high concentration of aerosols. Based on these results, it has been concluded that the COVID-19 may likely to increase during the dry period (high concentration of aerosols) of October-December, 2020 and post-spring season (April-June), 2021 in Pakistan. The industrial and economic growth has strongly affected around the world due to COVID-19 and special bail-out packages and relief operation were carried out to minimize its impacts to industrial, corporate, and commercial sectors as well as general public. It is highly recommended that the public should keep social distancing, use of face masks, and sanitizers, whereas government intervention should be made in high COVID-19 vulnerable areas in the form of smart lockdown that could reduce the COVID-19 transmission and help to fight the future outbreak.

Acknowledgements The authors acknowledge National Institute of Health (NIH), Ministry of Health, Pakistan for providing the COVID19 data; Global Change Data Lab (GCDL) for stringency index; Pakistan Meteorological Department (PMD) for weather data, and National Oceanic Atmospheric Administration (NOAA) for aerosols and ultraviolet data. 
Author Contributions All authors have made substantial contribution to this research and have approved the final manuscript. Arbab Siddique and Shahzada Adnan contributed on conceptualization, design, writing, and data analysis; Habib Bokhari and Muhammad Hanif contributed on concept and supervision. Asima Azam, Muhammad Suleman Rana, Muhammad Mujeeb Khan, and Shawana Sharif contributed in data acquiring, writing, and proof reading.

Funding None.

Availability of Data and Materials Available on request.

\section{Declarations}

Conflicts of interest The study was based on data available in public domain; therefore, no ethical issue and conflict of interest.

\section{References}

Abduljali JM, \& Abduljali BM (2020) Epidemiology, genome and clinical features of the pandemic SARS-CoV-2: a recent view. New Microbes and New Infections. 100672.

Abid K, Bari YA, Younas M, Tahir Javaid S, Imran A (2020) Progress of COVID-19 Epidemic in Pakistan. Asia Pac J Public Health 32:154-156

Adnan S, Hanif M, Khan AH, Latif M, Ullah K, Bashir F, Kamil S, Haider S (2020) Impact of Heat Index and Ultraviolet Index on COVID-19 in Major Cities of Pakistan. J Occup Environ Med. https://doi.org/10.1097/JOM.0000000000002039

Altamimi A, Ahmed AE (2019) Climate factors and incidence of Middle East respiratory syndrome coronavirus. J Infect Public Health 13:704-708

Badshah SL, Ullah A, Badshah SH, Ahmad I (2020) Spread of Novel coronavirus by returning pilgrims from Iran to Pakistan. J Travel Med 27:taa044

Bashir MF, Ma B, Komal B, Bashir MA, Tan D, Bashir M (2020) Correlation between climate indicators and COVID-19 pandemic in New York, USA. Sci Total Environ 728:138835

Budowsky EI, Bresler SE, Friedman EA, Zheleznova NV (1981) Principles of selective inactivation of viral genome. Adv Virol 68:239-247

Butt MJ, Mashat AS (2018) MODIS satellite data evaluation for sand and dust storm monitoring in Saudi Arabia. Int J Remote Sens 39:8627-8645

Butt MJ, Assiri ME, Ali MA (2017) Assessment of AOD variability over Saudi Arabia using MODIS deep blue products. Environ Pollut 231:143-153

Centers for Disease Control and Prevention (2020) CDC Works 24/7. https://www.cdc.gov/ mmwr/volumes/69/wr/mm6915e3. htm?s\%20cid=mm6915e3\%20w. Accessed August 1, 2020.

Centers for Disease Control and Prevention (2020) People 65 Years and Older \& Influenza. http://www.cdc.gov/flu/highrisk/65over.htm. Accessed August 8, 2020.

Chan KH, Peiris J, Lam S, Poon L, Yuen K, Seto W (2011) The effects of temperature and relative humidity on the viability of the SARS coronavirus. Adv Virol 2011:734690

Chen B, Jia P, Han J (2021) Role of indoor aerosols for COVID-19 viral transmission: a review. Environ Chem Lett 13:1-18

Clark A, Jit M, Warren-Gash C, Guthrie B, Wang HH, Mercer SW, Sanderson C, McKee M, Troeger C, Ong KL, Checchi F (2020) Global, regional, and national estimates of the population at increased risk of severe COVID-19 due to underlying health conditions in 2020: a modelling study. Lancet Glob Health 8:e1003-e1017

Davis RE, McGregor GR, Enfield KB (2016) Humidity: a review and primer on atmospheric moisture and human health. Environ Res 144:106-116

Davis RE, Dougherty E, McArthur C, Huang QS, Baker MG (2016) Cold, dry air is associated with influenza and pneumonia mortality in Auckland, New Zealand. Influenza Other Respir Viruses 10:310-313

Diekmann O, Heesterbeek JA, Metz JA (1990) On the definition and the computation of the basic reproduction ratio $\mathrm{R} 0$ in models for infectious diseases in heterogeneous populations. J Math Biol 28:365-382

Census report of Pakistan, (2017) http://www.pbs.gov.pk/sites/ default/files/PAKISTAN\%20T EHSIL\%20WISE\%20FOR\%20 WEB\%20CENSUS_2017.pdf. Accessed September 30, 2020.

Franch-Pardo I, Napoletano BM, Rosete-Verges F, Billa L (2020) Spatial analysis and GIS in the study of COVID-19: a review. Sci Total Environment 739:140033

Hale T, Webster A, Petherick A, Phillips T, Kira B (2020) Oxford COVID-19 government response tracker. Oxford, UK: Blavatnik School of Government. Data use policy: Creative Commons Attribution CC BY standard. https://www.bsg.ox.ac.uk/resea $\mathrm{rch} /$ research-projects/coronavirus-government-response-track er. Assessed February 10, 2021.

Hsu LY, Chia PY, Lim JF (2020) The Novel Coronavirus (SARSCoV-2) pandemic. Ann Acad Med Singapore 49:105-107

National Institute of Health (NIH). Daily COVID-19 cases. http:// covid.gov.pk/stats/pakistan. Accessed March 03, 2021.

Iqbal MM, Abid I, Hussain S, Shahzad N, Waqas MS, Iqbal MJ (2020) The effects of regional climatic condition on the spread of COVID-19 at global scale. Sci Total Environ 739:140101

Islam MS, Rahman M, Tusher TR, Roy S, Razi MA (2021) Assessing the Relationship between COVID-19, Air Quality, and Meteorological Variables: A Case Study of Dhaka City in Bangladesh. Aerosol Air Qual Res. https://doi.org/10.4209/aaqr.200609

Keilman LJ (2019) Seasonal influenza (flu). Nurs Clin 54:227-243

Ko G, First MW, Burge HA (2000) (2000) Influence of relative humidity on particle size and UV sensitivity of Serratia marcescens and Mycobacterium bovis BCG aerosols. Tuber Lung Dis 80:217-228

Labban AH, Butt MJ (2021) Analysis of sand and dust storm events over Saudi Arabia in relation with meteorological parameters and ENSO. Arab J Geosci 14:1-2

Ladiwala ZF, Dhillon RA, Zahid I, Irfan O, Khan MS, Awan S, Khan JA (2021) Knowledge, attitude and perception of Pakistanis towards COVID-19; a large cross-sectional survey. BMC Public Health 21:1-10

Lee S, Chowell G (2017) Exploring optimal control strategies in seasonally varying flu-like epidemics. J Theor Biol 412:36-47

Livadiotis G (2020) Statistical analysis of the impact of environmental temperature on the exponential growth rate of cases infected by COVID-19. PLoS ONE 15:e0233875

Loeffelholz MJ, Tang YW (2020) Laboratory diagnosis of emerging human coronavirus infections-the state of the art. Emerging Microbes Infect 9:747-756

Lowen AC, Mubareka S, Steel J, Palese P (2007) Influenza virus transmission is dependent on relative humidity and temperature. PLoS Pathog 3:1470-1476. https://doi.org/10.1371/journal.ppat.00301 51

Ma Y, Zhao Y, Liu J, He X, Wang B, Fu S et al (2020) Effects of temperature variation and humidity on the death of COVID-19 in Wuhan. China. Sci Total Environ 724:138226

McDevitt JJ, Rudnick SN, Radonovich LJ (2012) Aerosol susceptibility of influenza virus to UV-C light. Appl Environ Microbiol 78:1666-1669 
Meng Q (2017) The impacts of fracking on the environment: a total environmental study paradigm. Sci Total Environ 580:953-957

Mollalo A, Sadeghian A, Israel GD, Rashidi P, Sofizadeh A, Glass GE (2018) Machine learning approaches in GIS-based ecological modeling of the sand fly Phlebotomus papatasi, a vector of zoonotic cutaneous leishmaniasis in Golestan Province. Iran. Acta Trop 188:187-94

Morin CW, Stoner-Duncan B, Winker K, Scotch M, Hess JJ, Meschke JS et al (2018) Avian influenza virus ecology and evolution through a climatic lens. Environ Int 119:241-249

National action plan for preparedness \& response (NAPPR) to Corona virus disease (COVID-19) Pakistan. https//www.nih.org.pk/wpcontent/uploads/2020/02/NAP-covid-19_AL@version-3-date12-2-2020-with annexures.pdf. Accessed April 5, 2020.

Nikpouraghdam M, Jalali Farahani A, Alishiri G, Heydari S, Ebrahimnia M, Samadinia H et al (2020) Epidemiological characteristics of coronavirus disease 2019 (COVID-19) patients in IRAN: A single center study. J Clin Virol 127:104378. https://doi.org/10. 1016/j.jcv.2020.104378

Noreen N, Siddiqui SW, Niazi SUK, Khudaidad F, Khan NU et al (2020) COVID-19 Outbreak in Pakistan; a Situational Analysis. J Emerg Dis Virol. https://doi.org/10.16966/2473-1846.153

Noreen N, Naveed I, Dil S, Niazi S, Saleem S, Mohiuddin N, Khan N, Noor B, Khan M, Khan F (2020) Trend Analysis of exponential increase of COVID-19 cases in Pakistan: An interpretation. Global Biosecurity. 19:1

Pakistan Institute of Development Economics (PIDE) (2020) https:// www.pide.org.pk/pdf/PIDE-Covid-Blog-31.pdf. Assessed March 3, 2021.

Paz S, Semenza JC (2016) El Niño and climate change-contributing factors in the dispersal of Zika virus in the Americas? The Lancet 387:745

Organisation for Economic Co-operation and Development (OECD) (2021) Population (indicator). doi: https://doi.org/10.1787/d434f 82b-en .Accessed on 09 March 2021

Qi H, Xiao S, Shi R, Ward MP, Chen Y, Tu W et al (2020) COVID-19 transmission in Mainland China is associated with temperature and humidity: A time-series analysis. Science of the Total Environment 728:138778

Ridenhour B, Kowalik JM, Shay DK (2018) Unraveling r0: Considerations for public health applications. Am J Public Health 108:S445-S454

Saeed U, Sherdil K, Ashraf U, Younas I, Butt HJ, Ahmad SR (2021) Identification of potential lockdown areas during COVID-19 transmission in Punjab, Pakistan. Public Health 190:42-51
Sarwar S, Waheed R, Sarwar S, Khan A (2020) COVID-19 challenges to Pakistan: Is GIS analysis useful to draw solutions? Sci Total Environ 730:139089

Shi P, Dong Y, Yan H, Li X, Zhao C, Liu W, Xi S (2020) The impact of temperature and absolute humidity on the coronavirus disease 2019 (COVID-19) outbreak-evidence from China. MedRxiv 24:2020-2103

WHO Situation Report COVID-19 (2020) https://www.who.int/docs/ default-source/coronaviruse/situation-reports/20200324-sitrep64-covid-19.pdf?sfvrsn=703b2c40_2. Accessed March 03, 2021.

Steadman RG (1979) The assessment of sultriness. Part I: A temperature-humidity index based on human physiology and clothing science. J Appl Meteorol Climatol 18:861-873

Sugg MM, Spaulding TJ, Lane SJ, Runkle JD, Harden SR, Hege A, Iyer LS (2021) Mapping community-level determinants of COVID-19 transmission in nursing homes: a multi-scale approach. Sci Total Environ 752:141946

Torres OO (2006) OMI/Aura Near UV Aerosol Optical Depth and Single Scattering Albedo 1-orbit L2 Swath 13x24 km V003, Greenbelt, MD, USA, Goddard Earth Sciences Data and Information Services Center (GES DISC), Accessed June 6, 2020. https://doi. org/10.5067/Aura/OMI/DATA2004.

Tuite A, Bogoch I, Sherbo R (2020) Estimation of coronavirus disease 2019 (COVID-19) burden and potential for international dissemination of infection from Iran [published online March 16, 2020]. Ann Intern Med. https://doi.org/10.7326/M20-0696

Welch D, Buonanno M, Grilj V, Shuryak I, Crickmore C, Bigelow AW et al (2018) Far-UVC light: A new tool to control the spread of airborne-mediated microbial diseases. Sci Rep 8:1-7

Wilder-Smith A, Freedman DO (2020) Isolation, quarantine, social distancing and community containment: pivotal role for old-style public health measures in the novel coronavirus (2019-nCoV) outbreak. Journal of travel medicine. 27:taaa020.

World Air Quality Index (2021) Air quality in Punjab. https://www. iqair.com/us/pakistan/punjab. Accessed March 10, 2021.

Worldometer (2020) Countries where Coronavirus has spread. .https:// www.worldometers.in fo/coronavirus/countries-wherecoronavirus-has-spread/. Accessed October 11, 2020.

Wu X, Nethery RC, Sabath BM, Braun D, Dominici F (2020) Exposure to air pollution and COVID-19 mortality in the United States. medRxiv. 